\title{
Towards a neo-polanyian approach to money: integrating the concept of debt
}

Hadrien Saiag - hadien.saiag@gmail.com

Version 10/09/2013

Published as Saiag H 2014: "Towards a neo-polanian approach to money: integrating the concept of debt", Economy and Society 43 (4), pp. 559-581

\begin{abstract}
The paper aims to reconsider Polanyi's approach to money. His best-known writing on money uses (1968) is deeply original and presents strong insights that dissociate money from the concept of the market. Polanyi also developed an interesting non-dichotomous understanding of money in his Great Transformation (2001 [1944]). However, taken together, these two contributions lead to some unresolved questions: his critique of the orthodox approach to money is ambivalent; his argument to separate payment from account is weak; and, most important, he ultimately makes an incomplete break with the classical real/monetary dichotomy. This paper proposes a distinction between money as a set of instruments and practices and money as a concept, through the integration of John Commons' concept of debt into Polanyi's framework. This reformulation allows us to resolve Polanyi's unresolved questions while preserving his major contributions, and leads to a more complex understanding of money.
\end{abstract}

Keywords: Karl Polanyi, theories of money, debt, money plurality, economic anthropology, John Commons 


\section{Introduction}

Karl Polanyi's writings are now widely discussed in the social sciences, in particular his critique of the market system and his concept of embeddedness. However, his reflections on money remain largely unexamined. This is surprising, as Polanyi expressed an interest in the topic during his entire career, from the early 1920 's to his death ${ }^{1}$. While it is true that an earlier generation of economic anthropologists - some of them Polanyi's students - discussed his approach to money, most authors only took into consideration his later works. They discussed either his concept of special-purpose money (Bohannan, 1959; Dalton, 1965; Meltiz, 1970) or his distinction between payment and exchange-use of money (Grierson, 1978; Smith, 1983 - see also Moisseron, 2002; Poulain, 1998). Nowadays, only a few researchers still publish on Polanyi's views concerning money (Servet, 1993; Maucourant, 1994, 2002 and 2005; Blanc, 2006; Hart, 2009; 2011; Chopard, 1998). Except for Hart and Servet, even these authors do not take into account all of his monetary writings: they concentrate either on The Great Transformation (Polanyi, 2001 [1944]) or on his posthumous publications (Polanyi, 1966; 1968; and 1977). To my knowledge, none have questioned the unresolved questions that appear when considering Polanyi's work on money as a whole.

In this paper, I propose an internal critique of Polanyi's approach to money based on both his earlier and later publications (Polanyi, 2001 [1944]; 1957; 1966; 1968 and 1977). In all these texts, Polanyi developed an original approach to money, but one based on different considerations. In The Great Transformation, he argues for the specific nature of the market system, and does not explicitly offer an alternative view of money, contrary to his later writings. This leads to some interesting incoherences. My critique is internal: as a whole, I agree with Polanyi's key concepts, but take issue with his rich, yet sometimes inconsistent approach to money. It is a non-evolutionist approach which stems from Polanyi's intention to conceptualize money as separate from the market and from commodities. His originality lies in acknowledging a wide variety of money uses, and clearly distancing himself from any theory of value (either based on utility or labour, hence he conceives of money as a fictitious commodity). However, several problematic points appear at different levels of his argument: his position towards the functional approach to money, his perspective on the classical real/monetary dichotomy, and, finally, his approach to the institutionalization of different money uses. Based on both Polanyi's writings and John Commons' (2005 [1934]) concept of debt, I suggest a reformulation of Polanyi's argument, through the distinction between money as a set of instruments and practices and money as a concept. This approach solves the problems mentioned 
above while preserving Polanyi's major contributions and leads to a more complex understanding of money.

Special emphasis is devoted to Polanyi's attitude towards the classical monetary/real dichotomy of money. According to this view, it is possible to describe two independent spheres: the "real" one determines relative prices; while the monetary sphere only determines nominal prices (the quantitative expression of prices as regards to a standard of account). Therefore, money is considered to be a neutral veil, because it does not influence real values. I would argue that a suitable reworking of Polanyi's conception of money can overcome this approach, through a clearly non-dichotomous approach in which it is not possible to separate the real sphere from the monetary one. In this perspective, money is no longer a minor variable, but a key element of social reproduction.

The paper is structured as follows. Section one briefly looks at Polanyi's approach to money, as developed in The Great Transformation and his later writings. Section two highlights three inconsistencies found in Polanyi's understanding of money: his sometimes weak critique of the instrumental approach to money, his ambiguous approach to the unit of account, and, finally, his ambiguity with regards to the real/monetary dichotomy. Section three argues for the distinction between money as a concept and a set of instruments and practices, through the integration of Commons' understanding of debt into Polanyi's framework.

\section{A brief review of Polanyi's approach to money}

Polanyi's writings on money were published during two distinct periods. The most well known is the latter, particularly his posthumous article "The semantics of money uses" (Polanyi, 1968), in which he apprehends money according to its uses (see also Polanyi, 1957; 1977: chapters 9 and 16; and 1966: chapter 11). In these later writings, Polanyi attempts to clarify the concepts he uses. In contrast, in his earlier work, namely The Great Transformation (Polanyi, 2001 [1944]), Polanyi's concepts are embedded within a historical description, and this historical description itself is a conceptualization: his account of the nineteenth century self-regulating market utopia and its conceptualization are intertwined. This may explain why only a few scholars have analysed the place of money in The Great Transformation. Yet, I would argue that money plays a key role in Polanyi's argument, and that its analysis in the book is somewhat different from the one presented in his later writings. 
Polanyi developed a clearly non-dichotomous approach to money in The Great Transformation. Indeed, if the book is considered as a whole, it is evident that the analysis does not reproduce the classic distinction between two hypothetically separable spheres: the "monetary" and the "real" (Servet, 1993). This can be seen from the very beginning of the book, when Polanyi argues that the nineteenth-century self-regulating market system was supported by three main institutions: the balance-of-power system, the international gold standard, and the liberal state (Polanyi, 2001 [1944]: 3-20). The liberal state was less directly linked with money, yet Polanyi's approach to the balance-of-power system and the gold standard offer two important insights into his treatment of money.

First, Polanyi's analysis of the balance-of-power system highlights the importance of stable exchange rates between national currencies during the nineteenth century. Monetary stability is considered a prerequisite for the expansion of the market system. To understand this point, it is necessary to come back to the link between the balance-of-power system and what Polanyi called haute finance, which refers to the impressive and dissuasive power of the banking class. During the nineteenth century and at the beginning of the twentieth, financial investments requiring long-term immobilization of capital across countries (such as railways, participation in consortia, financial control of colonial companies, etc.) grew significantly. Because such investments were denominated in the great powers' currencies, they were highly sensitive to variations of exchange rates. Thus, monetary fluctuations would have put haute finance's business in jeopardy. Since war between the great powers would have run the risk of destabilizing the international monetary system (gold standard), haute finance became an "acute peace interest" (ibid: 7). However, decisions of peace or war are matters of sovereign states, not directly of haute finance: "[t]he motive of haute finance was gain; to attain it, it was necessary to keep in with the governments whose end was power and conquest" (Polanyi, 2001 [1944]: 12). Still, haute finance was able to impose its view on national governments because it faced relatively weak and dependent political powers. This was precisely the result of the balance-of-power system, which "merely postulates that three or more units capable of exerting power will always behave in such a way as to combine the power of the weaker units against any increase in the power of the strongest" (Polanyi, 2001 [1944]: 6). It allowed haute finance to occupy a strategic position, based on its ambivalence towards national governments: "independent of single governments, even the most powerful, it was in touch with 
all" (ibid: 10), because they constantly needed international loans in order to maintain the gold standard. Therefore, haute finance was able to influence governments' decisions through access to credit (as well as diplomatic pressure).

Secondly, Polanyi adopts a clearly non-dichotomous approach, considering money as a "fictitious commodity". Money plays a key role in the Great Transformation, since the (temporary) end of the market system is simultaneous with abandonment of the gold standard (during World War I and the 1930s). Moreover, fictitious commodity is a pivotal concept in the book. The book deals with the attempt to institutionalize a market system during the nineteenth and early twentieth century. This implied expanding the market's scope to all commodities, including "fictitious" ones, because they are key elements of the production process. Thus, although land, labour and money are not produced for sale, the commodity fiction acted as an "organizing principle of society" (ibid: 79). This led to the establishment of the gold standard, as well as land and labour markets in England. However, such transformations threatened the essence of society, because they aimed to submit man, nature and the productive organization to the hazardous fluctuation of prices. Therefore, a countermovement emerged against market forces, which intended to remove fictitious commodities from the scope of the market system. This countermovement was unplanned and no coherent whole emerged from it, leading to deep contradictions and, ultimately, the collapse of the market system.

Polanyi's understanding of the gold standard is deeply original. He conceives of its "pure version" as an attempt to commodify money, through strict regulation of how means of settlement are issued. Indeed, according to commodity theory, money is a nothing more than a commodity used more often as a means of indirect exchange (ibid: 202). As the advocates of the gold standard argue, because gold is money, bills merely represent the amount of gold available in the country, and politics should not interfere in the monetary sphere. Consequently, the available amount of means of settlement must fluctuate with the stock of gold. In treating money as a commodity, this "pure" version of the gold standard represents an extension of the scope of the market system. However, because for Polanyi money is not a commodity, the adoption of such a monetary system would jeopardize the productive organization, through the potential decrease in prices:

"Yet if profits depend upon prices, then the monetary arrangements upon which prices depend must be vital to the functioning of any system motivated by profits. While, in the long run, changes in selling prices need not to affect profits $[\ldots]$ this is not true in the short run, since there must be a time lag before contractually fixed prices change. [...] Hence, if 
the price level was falling for monetary reasons over a considerable time, business would be in danger of liquidation accompanied by the dissolution of productive organization and massive destruction of capital" (Polanyi, 2001 [1944]: 201).

Without any countermovement affecting money, crisis would be chronic.

According to Polanyi, money became the subject of a countermovement, in which Central Banks played a pivotal role (see especially Polanyi, 2001 [1944]: chapter 16). It acted as the interface between domestic and foreign trade. Indeed, while token monies were necessary to support domestic trade, foreign trade required a strong relationship between money and gold since no token money could circulate on foreign soil, contrary to gold (ibid: 202-203). Central Banks resolved this dilemma in two ways. The first tended to protect the economy against a short run on gold (due to a temporary imbalance of foreign payments). To do so, Central Banks took advantage of the increasingly free circulation of financial capital and expanded short-term public debt. They could also politically manage their gold reserves. If the run on gold dragged on, Central Banks would create a "buffer effect", through the centralization of the credit supply:

"Central banking mitigated this defect of credit money greatly [price decreasing in the event of a gold run]. By centralizing the supply of credit in a country, it was possible to avoid the wholesale dislocation of business and employment involved in deflation and to organize deflation in such a way as to absorb the shock and spread its burden over the whole country. The bank in its normal function was cushioning the immediate effects of gold withdrawals on the circulation of notes as well as the diminished circulation of notes on business" (ibid: 203).

The buffer effect "socialised" the cost of deflation. If, for instance, a particular region or industry faced a shortage of money as a result of a trade deficit, the cost of this deficit was bore by the nation as a whole: interest rates would rise throughout the country, but not as high as they would have locally in the absence of the Central Bank. Thus, Polanyi argued, political management of money tended to extract it from the scope of the market system.

In The Great Transformation, money enjoys a very special status among fictitious commodities: it involves society as a whole. As Polanyi argues, faith in the gold standard was the only ideology shared by whole nations: 
"Belief in the gold standard was the faith of the age. With some it was a naïve, with some a critical, with other a satanistic creed implying acceptance in the flesh and rejection in the spirit. Yet the belief itself was the same, namely that banknotes have value because they represent gold. Whether the gold itself has value for the reason that it embodied labour, as the socialist held, or for the reason that it is useful and scarce, as the orthodox doctrine ran, made for once no difference [...]. The essentiality of the gold standard to the functioning of the international economic system of the time was the one and the only tenet common to men of all nations and classes, religious denominations, and social philosophies" (ibid: 2627)

It is then unsurprising that the countermovement affecting money involved entire nations. This contrasts deeply with double movements of land and labour: because their commodification threatened primarily the defeated classes of the industrial revolution (the working class, peasantry and landlords), these classes alone were involved in the countermovement affecting those commodities. On the contrary, the gold standard menaced the productive organization of society itself, and not a specific social class. As such, even the victors of the industrial revolution (the trading class and the bankers) were fervent proponents of Central Bank policies, which aimed to protect money from its commodification. The countermovement led to the abandon of the gold standard which, in turn, meant the beginning of the Great Transformation: "final failure of the gold standard was the final failure of market economy" (ibid: 209).

Clearly such an approach to money does not reflect the classical dichotomous view whereby "monetary" and "real" spheres are supposed to be independent. On the contrary, in Polanyi's argument, it is not possible to separate the rise and fall of the market system from monetary policies and the collective representation of money, both because monetary stability was a requisite for the expansion of the market system and because money is conceived as a fictitious commodity.

\section{Understanding money through its uses}

The conceptualization of money presented in Polanyi's later writings openly opposes the approach developed by "orthodox" economics, according to which money is first and foremost a "means of exchange" (Polanyi, 1977: 104-105), i.e., the natural outcome of individual actions in markets to facilitate barter transactions (Menger, 1892). Polanyi's main critique is that in such an approach, money is subordinated to the status of a vehicle of the market system, "[t]rade appear[s] as the 
movement of goods in the market, and money as the means of exchange which facilitate[s] that movement" (Polanyi, 1977: 77).

The originality of Polanyi's critique of the means-of-exchange approach is twofold. First, it is based on observing a wide range of money uses, which should not be assimilated with money functions. Indeed, as Blanc (2006) convincingly argues, in order to understand Polanyi's approach, it is necessary to distinguish between monetary functions, instruments and uses: functions consist of the general principles of money; the instruments are the concrete applications of the functions (token units of account, physical forms of the objects used as payment, etc.); money uses refers to the way those instruments are deployed. As such, while monetary functions are few, its uses and instruments are much more diverse (Polanyi, 1977: 102). According to Polanyi, the means-of-exchange approach only refers to a specific kind of money use (exchange) when in fact money is used in situations unrelated to the market system. Because he refused evolutionism (Polanyi, 1977: 42), he did not reject the "exchange-use" of money per se: probably no society ignored market places, in which money acts as "means of exchange". Rather, he supplements the approach with the concepts of payment and "standard of value" 2 ".

Payment refers to a very different rationale than exchange-use: that of social reproduction.

"Payment is the discharge of an obligation through the handing-over of quantifiable objects, which then function as money. [...] Yet the quantification, which we associate with payment, operated already at a time when the obligations discharged were quite unconnected with economic transactions. The story starts with the propinquity of payment and punishment on the one hand, obligation and guilt on the other. No unilineal development should be inferred, however. Rather, obligations may have origins different from guilt and crime, such as wooing and marriage; punishment may spring from other than sacral sources, such as prestige and precedence; eventual payment, [...] may include operational elements not entailed in punishment as such" (Polanyi, 1968: 181)

In this quotation, payment is due to the changing status of human beings and their place in society, due to birth, death, wooing, marriage, compensations for death or injuries, etc. (see also Breton 2002). A few paragraphs later (ibid: 182), Polanyi expands the payment-use of money to the recognition of and subordination to a centralized power, through the payment of fines, tax, or sacrifice to gods. Under this rationale, payment emerges as a complex element that can be found in very different (market and non-market) societies. 
The third money-use presented by Polanyi is the "standard of value". It refers to any object or token involved in the evaluation of either commodities or obligations:

"For barter and storage of staples are the two very different sources from which the need for a standard springs. At first sight the two have little in common. The first is akin to transaction, the other to administration and disposal. Yet neither can be effectively carried out in the absence of some standard. For how otherwise than with the help of computation could, for instance, a piece of land be bartered against an assortment consisting of a chariot, horse-harness, asses, ass-harness, oxen, oil, clothes and other minor items? [...] The same principle applied, in the absence of exchange, to the administration of vast palace and temple stores (staple finance). Their keeper handled subsistence goods under conditions which, from more than one angle, required a gauging of the relative importance of these goods. Hence the famed rule of accountancy of "one unit of silver = one unit of barley" on the stele of Manistusu as well as at the head of the Laws of Eshunna" (Polanyi, 1968: 184-185).

The concept of standard of value encompasses two different rationales: individual interests and the centralized and political administration of vast territories. Despite differing rationales, both face the same central question: how to find a uniform evaluation of heterogeneous commodities and obligations? By asking this question, Polanyi implicitly recognizes that it is necessary to introduce an element exterior to the concept of commodities. This point is of overwhelming importance, because it leads to a non-dichotomous approach, in which "real" and "monetary" spheres are closely interlinked. However, Polanyi seems not to realize it entirely: according to him, the standard can either be an abstract unit of account or a commodity used in order to "reckon" other commodities (Polanyi, 1977: 277). And yet, if a commodity is used in such a way; it can no longer be considered as a common commodity: it enjoys a special status, the social expression of value.

The second originality of Polanyi's later critique of the orthodox approach to money is his claim that different money uses have been "institutionalized separately" (Polanyi, 1968: 185). His argument is based on the observation of several special purpose monies (ibid: 178-180), which were only used either as payment, standard or exchange, or as one of these three categories within a specific sphere of circulation (such as elite or subsistence goods). Contrary to the means-ofexchange approach, payment and standard uses are not necessarily the result of money's exchangeuse. 
On this basis, Polanyi asserts both the universality and diversity of money-uses. According to him, no society ignores money: "[f]oreign trade and some money uses are as old as mankind" (Polanyi, 1977: XL - see also Polanyi 1966: xxiii ${ }^{3}$; Servet, 1993; and Maucourant, 2005 for a critique). Of course, Polanyi is not the first author to insist on the universality of money: Innes (2004 [1913]) did so before him ${ }^{4}$. Polanyi's originality lies in acknowledging that the universal character of money is precisely due to its wide variety of uses: universality goes hand in hand with diversity (Servet, Théret and Yildirim, 2008). Even societies with little knowledge of the market system did not ignore money: used as a form of payment, it is embedded in a wide range of social relations.

\section{Three unresolved questions}

Polanyi's approach to money is deeply original. However, it is not without incoherences. I will examine three of them, as revealed by his sometimes weak critique of the orthodox approach to money, his treatment of payment and exchange as being independent from the unit of account, and, finally, his incomplete break with the dichotomous approach.

\section{A sometimes weak critique of the orthodox approach: Polanyi's "exchange-use"}

Polanyi's relationship to the "orthodox" approach to money is ambiguous. On the one hand, The Great Transformation critically challenges the view that money is merely a means of indirect exchange between individuals. Indeed, even through the gold standard, money was not a commodity; it was politically managed by central banks. Moreover, because central banks are understood as institutions aiming to protect societies against the risk of business destruction, money is considered as an institution which involves society as a whole. On the other hand, Polanyi makes some concessions to the "orthodox" approach to money in his later writings. He does not point out its inadequacy when faced with money in contemporary society. He simply critiques this conception of money as "too narrow" (1977: 104) to be valid for all societies, since the exchange-use of money is marginal in economies in which the market system is not predominant (Polanyi, 1968: 179).

But what about money in market societies? Polanyi's argument is quite poor in his later writings, as compared to The Great Transformation. Moreover, because his critique is centred on "non-market" economies, he implicitly admits the pertinence of the orthodox approach as regards the "exchangeuse" of money: "[w]e believe that such a[n] [orthodox] definition is biased by a modernizing approach to the problem, which is partly responsible for the obscurity in which the characteristics of 
primitive money still abide" (Polanyi, 1977: 104-105 - emphasis added). It is interesting to note that Polanyi uses the term "biased", and not "false", "wrong", or "irrelevant": according to him, something must be correct in this approach. Therefore, he accepts Menger's (1892) reasoning, but only limited to a restricted sphere:

"Exchange use of money is the use of quantifiable objects for indirect exchange. The sociological situation is that of the possession of some objects together with the desire for other objects. The operation consists of acquiring units of quantifiable objects through direct exchange in order to acquire other objects through another act of exchange" (Polanyi, 1968: 192-193 - emphasis added)

It is almost as if the operations described do not refer to money: objects are valued for their expected utility, and exchanged for other objects. According to this formulation, money arises from the world of commodities: it is merely an act of exchange between individuals.

This account of the exchange-use of money reveals a serious limitation in Polanyi's writings: he does not offer a fully satisfactory alternative to the orthodox approach ${ }^{5}$. Indeed, he does not provide a strong alternative to the notion that money is the result of individual acts of barter (the "barter myth" - Servet 2001). Of course, he convincingly argues that individual acts of barter cannot be, historically, at the origin of the "exchange-use" of money because it requires a specific institutional background: the market system (see for instance Polanyi 1968: 202). This is a great limitation to the barter myth. However, once the market system is in place, Polanyi considers barter a relevant mode of action:

"Barter, truck, and exchange is a principle of economic behaviour dependent for its effectiveness upon the market pattern. [...] Unless such a pattern is present, at least in patches, the propensity to barter will find but insufficient scope: it cannot produce prices. [...] the principle of barter depends for its effectiveness on the market pattern" (Polanyi, 2001 [1944]: 59 - emphasis added)

The market system is described without referring to money, as in the orthodox view. Polanyi provides no alternative view of the "exchange-use" of money. This is highly surprising, given Polanyi's approach to the gold standard in The Great Transformation.

The question of the unit of account 
The second limitation in Polanyi's writings concerns his treatment of the unit of account. Admittedly, The Great Transformation does not openly tackle this question. However, it treats money mainly from the perspective of this unit of account, in two ways (see section one above). First, Polanyi emphasises the importance of stable exchanges rates in order to preserve haute finance's interest. Second, and more important, central banks are described as entirely preoccupied by the stability of the unit of account, because the productive organisation would be jeopardize by deflation. However, Polanyi's awareness of the importance of the unit of account seems to weaken when he argues that payment, account and exchange uses of money have been "institutionalized separately" (Polanyi, 1968: 185). Admittedly, he does argue that exchange did not necessarily involve payment, and vice-versa. But what about the unit of account? If, as Polanyi argues, it has been institutionalized separately from other money uses, accounting should happen independently from payment and exchange (Meltiz, 1970). And yet, I would argue, both exchange and payment uses cannot be understood without referring to the unit of account, and vice-versa.

In his later writings, Polanyi himself hardly separates accountancy from other money uses. On the one hand, he always refers to the unit of account in order to present both payment and exchangeuses. His argument concerning the exchange-use of money appears clearly in a quotation reproduced in the first section of this paper, in which he explains that barter [exchange] "could not be effectively carried out in the absence of some standard", since this operation required a "mechanism of computation" to express the relative values of commodities (Polanyi, 1968: 184185). He conversely argues that payment involves accountancy, when he distinguishes between payment and social obligations:

"Obligations are, as a rule, specific, and their fulfilment is a qualitative affair, thus lacking an essential of payment (its quantitative character). [...]

The specific characteristic in the payment-use of money is quantification. Punishment approximates payment when the process of riddance of guilt is numerable, as when lashes of the whip, turns of the praying mill, or days of fasting dispose of the offence" (ibid: 181-182, emphasis added)

Therefore, payment embodies a quantitative dimension that is absent from obligations. If the specificity of payment-use is indeed its quantification, how, then, could it be separated from accountancy? Clearly, according to Polanyi himself, exchange and payment involve the unit of account. 
Furthermore, in Polanyi's later writings, accountancy systematically involves either payment or exchange. Indeed, there is only one situation in which Polanyi deals with the accounting use of money without referring explicitly to the other money uses: the computation involved in the operation of storage of prestige or subsistence goods by a centralizing administration. And even here, Polanyi implicitly recognizes that such an operation also involves payment: "Treasure goods, which happen to be quantifiable, may be used for payment. [...] Such objects, when used for the discharge of obligations, i.e., for payment are stored at the centre whence they revert through redistributive payment and are consumed" (ibid: 187-188 - emphasis added). Therefore, "treasure goods" involve accounting and payment in two ways: first, when goods converge as payment of an obligation to a centralized authority; second when they are redistributed by the authority, as payment to the people and institutions that depend on it.

Accounting thus enjoys a special status among Polanyi's money uses: it is a prerequisite for both payment and exchange uses, and it cannot happen independently from them. Therefore, a neoPolanyian approach to money must clearly express this specificity.

\section{An incomplete break with the dichotomous approach}

Polanyi's ambivalence with regards to the classic real/monetary dichotomous approach may be his most serious problem. As underlined in the previous section, The Great Transformation clearly distances itself from such a dichotomy. Because money is conceived as a fictitious commodity, it would not make sense to separate the "real" sphere from the "monetary" one: rather, money is a driving force of nineteenth century economic and political transformations. However, Polanyi's later works are unclear: while the analysis of concrete transactions highlights a non-dichotomous approach, his general definition of money remains dichotomous.

In his later writings, Polanyi's analysis of the role of money in social stratification is not dichotomous. Indeed, both payment and monies' limited fungibility act as driving forces of unequal social status. Payment translates differences of power and status in the economy and, therefore, tends to reproduce them. Payer and payee are not in the same footing:

"Payment was due alike from the guilty, the defiled, the impure, the weak and the lowly; it was owed to the gods, and their priest, the honoured, the pure, and the strong. Punishment, 
accordingly, aimed at diminution in power, sanctity, prestige, status, or wealth of the payer, not stopping at his physical destruction" (ibid: 181; see also pp.182-183)

Payment enables a considerable transfer of wealth and power from the dominated to the dominators, without having to use physical force. It substitutes for physical violence (Graeber, 2009). Similarly, money's limited fungibility reinforces social stratification through unequal access to the different kinds of means of payment and exchange among social groups (see also Akin and Robbins, 1999 and Cartelier, 2007). In Polanyi's terms, monies are "ranked":

"On more advanced level of societal development, the idea of ranked money may also find application. Full six centuries before our time, Ibn Batutah recorded thin and thick copper wires of definite weight functioning as currency side by side on the Middle Niger in Gogo, a city in the Negro empire of Mali (1352). Thin wires were poor man's money, exchangeable for firewood and common millet. Thick wires bought anything, including horse, slaves, or gold, indeed all the elite goods that convey standing." (Polanyi, 1977: 117-118; see also Polanyi, 1966: chapter 11).

Polanyi underlines here how payment and momey's limited fungibility are key elements of social stratifications which, in turn, cannot be understood without referring to money. This approach is clearly not dichotomous.

However, Polanyi only makes an incomplete break with the classical "real/monetary" dichotomy. This is first due to the use of the expression "standard of value", instead of "unit of account". Indeed, contrary to the latter, the former presupposes the existence of a theory of value according to which relative prices are determined in the "real" sphere (Courbis, Froment and Servet, 1990; Orléan, 2011: 168-170). Second, and most importantly, Polanyi at times argues for a functional approach to money:

"[the student of early economic institutions] has to aim, as does the philosopher, at a functional definition: for no material object is money per se, and any object, in an appropriate situation, might function as money. To determine the use to which the physical things are put, he will point to the situation in which the objects are used and to what effect. The functional definition of money starts from the quantifiable objects commonly designated as money and the observable operations that are performed with these objects" (Polanyi, 1977: 100 - emphasis added; see also Dalton's (1965) last sentence) 
Of course, as mentioned above, Polanyi's approach to money is much more complex than the classical tri-functional definition. However, this does not appear clear to Polanyi himself, since he also assimilates payment, exchange and accounting (standard) as generic functions. And yet, any functional approach is dichotomous, since monetary functions are defined in relation to a supposedly "real" sphere (Théret, 2008: 819-823). Indeed, according to such an approach, commodities have a value (either because of their "embodied labour" or their "utility") and can be exchanged without referring to money. Money is a "neutral veil" because it only facilitates such process through its "functions". To achieve such an intellectual construction, it is then necessary to suppose that the "real" can be described without referring to the "monetary" sphere, which is precisely a dichotomy. In the next section I argue that Polanyi confuses the objects involved in money uses (which perform some "functions") and the concept of money as such (Aglietta, 1988).

\section{Distinguishing between concept and practices: a reinterpretation}

Despite these unresolved questions, Polanyi's approach to money must not be rejected. Indeed, few authors whose insights rely on a non-dichotomous approach to money claim that its inner logic comes from outside the market sphere and emphasize the wide diversity of monetary practices. By doing so, Polanyi provides strong arguments against the "barter myth" (Servet, 2001). Therefore, I suggest a reinterpretation of Polanyi's approach to money through the distinction between two different levels of abstraction: money as a concept and money as a set of instruments and practices. Polanyi's work embraces both, but does not clearly distinguish between them. (I believe this is the greatest source of confusion in his work). The great transformation is certainly concerned with the way money was managed by central banks, but it also discusses the concept of money, although not explicitly. On the other hand, his later works are more concerned with monetary practices, but they also provide insights into the concept of money. A neo-Polanyian approach to money would question those two levels of abstractions together, while preserving Polanyi's major contribution.

The first step towards such an approach is to identify and clarify Polanyi's issues as regards the concept of money. The previous section underlined three major contributions from The great transformation: money is not a commodity, it involves the society as a whole and it does not fit into the classical "real/monetary" dichotomy. It is however possible to go further and highlight three other key elements from Polanyi's work. First, in The great transformation, he considers money to be a "token of purchasing power" and refuses to distinguish between "real" and "token money" (Polanyi, 2001 [1944]: 71). Second, Polanyi rejected both the classical and Marxist labour theory of 
value $^{6}$. He is explicit about his rejection of the classical version, as it "reduce[s] all conceivable transactions in economic society to the principle of equal exchanges in a society of free men" (Polanyi, 2001 [1944]: 132). And even if he does not explain the reasons for his objection to the Marxist theory of value, I would argue that any theory of value is incompatible with Polanyi's monetary writings. Indeed, he insists on the interdependence between money and the "real" sphere, as well as on the potential role of money in reproducing social inequity; this contradicts theories of value according to which the most important elements of transactions (the "relative prices") are determined in the "real" sphere. Third, the distinction between exchange and payment in Polanyi's later writings' is a conceptual one. Indeed, he does not only describe the way monetary instruments are used; he also emphasizes the contrastive social relations they tend to reproduce. For sure, this distinction is an important element of Polanyi's aim to conceptualize money as distinct from the market system.

However, Polanyi does not provide a key concept that would allow us to link these conceptual findings consistently. This is probably due to his refusal to address the question of the nature of money $^{7}$. Yet, with Ingham (2004), Aglietta and Orléan (eds., 1998) and Théret (ed. 2007), I would argue that it is crucial to tackle this question and that is why Polanyi's works are sometimes confusing. It is therefore necessary to develop a concept that does not appear in his own work.

Integrating John Commons' (2005 [1934]: chapter 9) concept of debt into Polanyi's framework can significantly strengthen the latter's argument ${ }^{8}$. Admittedly, considering money as a system of evaluation and settlement of debt is not unique to Commons: it was proposed before him by the chartalist school (Innes, 2004 [1913]; Knapp, 1973 [1905]; Keynes 1965 [1930] - see also Wray, ed., 2004). Commons' "transactional approach" is particularly interesting for two reasons. First, it highlights the importance of relationships of indebtedness, because Commons considers that every "transaction" involves a debt transfer: on the one hand, the seller must settle a "performance debt", delivering a commodity or a service to the buyer; on the other hand, the buyer must settle a "payment debt" to the seller, through the transfer of a certain amount of money. Hence, the term "transaction" is preferred to "exchange", because the former links commodity circulation to debt, while the latter is restricted to the "real" sphere.

Second, and most important, Commons' approach can be used to translate into a debt perspective Polanyi's distinction between payment and exchange. Following Knapp, Commons underlines the existence of two different kind of debts (evaluated and paid by money) through his distinction 
between debts that can be discharged (releasable debt) and debts that cannot be repaid (unreleasable debts): "Historically it is more accurate to say that the bulk of mankind lived in a state of unreleasable debts, and that liberty came by gradually substituting releasable debs" (Commons, 2005 [1934]: 390). However, it is necessary to adopt a critical reading of Commons' unreleasable debts (Dutraive and Théret, 2011). In chapter nine of Institutional Economics, Commons tackles the question of the relationship between money and releasable debts. He briefly mentions unreleasable debts, but he associates them with taxes ${ }^{9}$ : citizenship requires regular payments that cannot be avoided except at the cost of one's exclusion from the community. This position is too narrow to be integrated into Polanyi's framework as it is. It is necessary to extend the scope of unreleasable debts to any kind of debt, which deals with the changing status of human beings: the debts can never be completely repaid, since individuals always belong to social entities (Théret, 2009). In this perspective, the concept of unreleasable debt is not restricted to "primordial debt", according to which society is considered as "a single totality to which everyone is born with a set of obligations" (Graeber, 2009: 119): it also includes, for instance, debts linked with life-cycle events, such bridewealth and bloodwealth (see Rospabé, 1995). I would argue that the singularity of Polanyi's exchange-use is that it is possible to release the debt incurred during the transactions, contrary to payment (which is rooted in individuals' relations with society).

Such a reformulation of Common's approach to debt and its insertion into Polanyi's framework leads to two contributions. On the one hand, it articulates Polanyi's key conceptual findings: they can all be deduced from the debt perspective. (Money is not a commodity, but a system of accounting and settlement of debts; it involves the society as a whole because social life engenders debts; and any theory of value independent from money should be rejected since price structure is a result of the way debts are evaluated). On the other hand, it provides answers to Polanyi's unresolved questions (highlighted in the previous section). First, if money is a system of evaluation and settlement of debts, then monetary practices consist of both accounting and settlement. The question, therefore, is no longer whether payment, exchange and accounting can be observed separately from each other, but what kind of debts are evaluated and settled in each monetary practice. Payment and exchange-uses refers to sub-categories of debt (Moisseron, 2002: 144-145), while settlement and account should be considered as "generic properties" of money (Ingham, 2002: 124; Théret, 2008: 819 - 823). Second, this approach is clearly non-dichotomous. The "real" sphere cannot be described without referring to money, since every transaction involves a credit/debt relationship evaluated and settled by money (see Ingham, 2004: 69-74; and Aglietta, 2007). Third, because it is clearly non-dichotomous, this approach provides a sound alternative 
view of money according to which it can be reduced to an instrument in the service of the real sphere.

Polanyi's main originality lies in having carried out together an investigation of the concept of money and of monetary practices (or money-uses): the former is based on observation of the latter, and vice-versa. In his work, he constantly switches back and forth between these two levels of abstraction. The reformulation of Polanyi's approach suggested here leads to a wider understanding of money than the one allowed by an exclusive focus on the concept of money. First, it allows us to identify the wide range of material forms of means of settlement: if money is a system of evaluation and settlement of debt, any object can act as a means of settlement once it is involved in the circulation of debts, regardless its material form. Second, it allows us to adopt a historical understanding of the transformations of money forms, rather than a static (conceptual) view. This appears clearly in Polanyi's comparative perspective, both in The great transformation and his later works: while the concept of money remains stable throughout time, monetary instruments, practices and institutions are constantly evolving with society itself. This perspective also implicitly raises the question of what changes in monetary institutions would be desirable for the future. Third, this reformulation of Polanyi's framework leads to a more complex understanding of money: following Hart (1986; 2007), money can be understood as both abstract and concrete; credit and debt. Money is both an abstract concept and a set of concrete practices and instruments. As a concept, it is first and foremost a debt relationship which reminds that people are living in society. As a set of means of settlement, it is also a source of credit in the society that accepts it. As credit, money allows people to act in society, either through their insertion into the social division of labour or through their participation to other aspects of social life (such as marriage, death ceremonies, prestige expenditures, etc.). Moreover, it is precisely because money is also a credit that unequal access to the means of settlement can be an active force of social stratification, as described in Polanyi's works.

Finally, and most important, this proposed reformulation of Polanyi's work avoids "hypostasis of money", according to which money would necessarily reduce "traditional" social relationships to market versions (i.e. between commutable individuals considered as equal), in any place and at any time (Cartelier, 2007). Polanyi's work already provides a strong antidote to this view. On the one hand, he insisted that in a wide range of societies money goes far beyond market relationships: even societies in which market price-making system is unknown display complex monetary systems. In those societies, money can be vector of social stratification, but not necessarily (see also the 
Wodani society analyzed by Breton, 2002). On the other hand, Polanyi argued that the attempt to fully integrate money into the market system (through its "fictitious commodification") is a political project specific to western civilization in a specific historical period, which is doomed to fail. My proposed reformulation of Polanyi's work aims to clarify this argument, linking those observations to a theoretical inquiry. It enables us to go beyond the enumeration of money-uses unrelated to the market system, analyzing how they are inserted in the general logic of evaluation and settlement of debts. Indeed, defining money as a system of evaluation and settlement of debt says nothing about the kind of social relationships promoted by money uses. It is also large enough to embrace Polanyi's wide set of monetary practices. Most important, it extends Polanyi's argument in two ways by adding the distinction between releasable and unreleasable debts. First, money does not necessarily lead to market relationships precisely because it is involved in both releasable and unreleasable debts and because the latter necessarily involve long-term relationships. Second, money itself does not render all debts "releasable" (taxes or tributes, for instance, involve regular payment). Rather than considering money as a vehicle of the market system, this reformulation of Polanyi's argument helps us to conceive of each currency as the image of the society in which it is inserted.

\section{CONCLUSION}

Polanyi proposed a deeply original approach to money, based on observations of money uses and the gold standard. His main contributions were to avoid the classical "real/monetary" dichotomy, to emphasize that money's inner logic differs from the one of commodities and the market system, and to underline the plurality of money-uses and instruments. On this basis, he pointed out the universal character of some money-uses. However, Polanyi's formulation is sometimes ambiguous and leads to several unresolved questions. Therefore, I propose a reformulation of Polanyi's framework through the distinction between money a set of instruments and practices and as a concept, incorporating John Common's understanding of debt. Money thus appears as both a unified concept and a fragmented set of practices and instruments (see also Blanc, 2000: 43). Polanyi's main source of originality is to have implicitly juggled between those two levels of abstraction.

One of the challenges faced by contemporary Polanyian scholarship is to link the two levels of abstraction in the analysis of contemporary societies explicitly (since Polanyi's argument is based on analysis of past events). A two-step avenue of investigation should be discussed. The first would be to adapt Polanyi's idea of special purpose money to modern societies (Blanc, 2006) in order to 
highlight the diversity of monetary uses and instruments, in several different ways. This would mean analyzing how the (ideal) norm of having a sole unit of account within nation states emerged during the $\mathrm{XIX}^{\text {th }}$ century through the affirmation of national sovereignty (Helleiner, 2003), while money plurality was previously a key feature of social organizations (Kuroda, 2007 and 2008; Fantacci, 2005; Guyer, 2004; Romano, 1998; Servet, Théret and Yildirim, 2008;). It is then possible to show that plurality is inherent to modern monies through the distinction between the unit of account and the means of settlement: while the uniqueness of the unit of account is considered as a norm, means of settlements are usually issued by different entities (commercial banks, treasury, etc.). Moreover, the uniqueness of the unit of account is the result of a specific institutional framework through which each commercial bank money is made equal to central bank money (Théret, 2008:821-823). Without such an institutional framework, different exchange rates are likely to appear, as it happened with the Argentinian experience of provincial fiscal currencies (Théret and Zanabria, 2009). It could be argued that the uniqueness of money in each nation is challenged both by international and sub-national forces (Hart, 1986), such as international financial derivatives (Bryan and Rafferty, 2007; Théret, 2008), monetary unions (Dodd, 2005), use of foreign currencies, inter-enterprise barter networks (Ould-Ahmed, 2008), electronic currencies, complementary currency systems, etc. Finally, how people juggle between different kinds of debts in their everyday monetary practices, despite the uniqueness of the unit of account, could be investigated. In this regard, Zelizer's (1994) analysis of how American citizens used to differentiate between monies through earmarking practices provides a strong insight against the temptation to homogenize monetary practices in contemporary societies.

However, the reformulation of Polanyi's framework proposed here suggests that we should go beyond mere descriptive accounts of money plurality. A second step would be to question the concept of money on the basis of observing a wide range of monetary practices and instruments. This raises the question of inserting multiple practices and instruments into a general logic of evaluation and settlement of debts, where the observed practices refer to a unified system of evaluation and settlement of debts. Are multiple instruments aimed at settling the same kind of debts? Do we observe separate systems of evaluation and settlement of debt? If the answer is yes, this raises in turn the question of the interfaces between monetary spheres (see Guyer, 2004). To answer these questions, it is necessary to extend our traditional focus on monetary practices in two ways: to consider the whole range of people's monetary practices and to questioning how debts are evaluated. This last point remains largely underexplored. 


\section{Acknowledgments}

I am deeply grateful to Jérôme Blanc, Keith Hart, Isabelle Hillenkamp, Chris Holms, André Orléan, Jean-Michel Servet, Bruno Théret, the participants of the workshop New Directions in Polanyian Scholarship (Centre for Citizenship, Globalization and Governance, University of Southampton, UK, $12^{\text {th }}$ and $13^{\text {th }}$ of March 2011) and the four anonymous readers for their comments on earlier versions of this text.

\section{Notes}

1For more details on Polanyi's approach to money during the 1920's, see Maucourant (1994).

2Polanyi sometimes includes a fourth money-use, subordinated to payment: hoarding of wealth. See Servet (1993) for a critique.

3 " [T] rade, money, and markets did not issue from a common matrix; and in fact had independent origins. The origins of trade and money are buried in the prehistory of mankind, while markets are a more recent development" (Polanyi, 1966: xxiii - emphasis added)

4After having defended that money is a credit-debt relationship, he writes: "The sanctity of an obligation is, indeed, the foundation of all societies not only in all times, but at all stages of civilisation; and the idea that to those whom we are accustomed to call savages, credit is unknown and only barter is used, is without foundation” (Innes, 1913: 391). Similar argument is developed by Grierson (1978).

${ }^{5}$ It also contradicts Polanyi's own observation of the ancient Greek practice whereby the value of local coins differed widely from the value of the material which formed the coins (Polanyi, 1977: chapter 16).

${ }^{6}$ In a review of M. Dodd's Studies in the Development of Capitalism (New-York, International Publishers Company, 1947), Polanyi considers that "Non-Marxists among the representatives of institutionalist methods in economic history [...] will feel that Mr Dodd is keeping what is bad and discarding what is good in Marxism. Instead of loosening its dependence on economic orthodoxies such as the labour theory of value, it is drifting away from its fundamental insight into historically limited nature of market organization” (Polanyi, 1948: 207 - emphasis added).

7 "Money is an incompletely unified system, a search for its single purpose a blind alley. This accounts for the many unavailing attempts at determining the "nature and essence" of money" (Polanyi, 1968: 175)

${ }^{8}$ Admittedly, Polanyi himself used the term debt in some notes for his students, published at the end of "The semantics of money-uses" (Polanyi, 1968: 190-203). However, Polanyi's use of the term is confusing: it is sometimes involved in specific forms of payment (pp. 190-197), and sometimes used as a synonym of obligation (pp.197-199).

9 "The first [compulsory debts] we shall name Taxes, as typical of all compulsory debts owning to governments, and the second we shall name Debts as typical of voluntary debts [...]" (Commons, 2005 [1934]: 463). 


\section{References}

Aglietta, M. (1988). L'ambivalence de l'argent. Revue Française d'Economie, 3(3), 87-133.

Aglietta, M. (2007). Universalité et transformations de la monnaie : la nature des crises monétaires. In B. Théret (Ed.), La monnaie dévoilée par ses crises (Vol. 2, pp. 7-41). Paris: Editions de l'EHESS.

Aglietta, M., \& Orléan, A. (Eds.). (1998). La monnaie souveraine. Paris: Odile Jacob.

Akin, D., \& Robbins, J. (Eds.). (1999). Money and modernity : State and local currencies in Melanesia. Pittsburgh, Pa.: University of Pittsburgh Press.

Blanc, J. (2000). Les monnaies parrallèles: Unité et diversité du fait monétaire. Paris: L'Harmattan.

Blanc, J. (2006). Karl Polanyi et les monnaies modernes: un réexamen. In G. Lazuech \& P. Moulévrier (Eds.), Contributions à une sociologie des conduites économiques (pp. 51-66). Paris: L'Harmattan.

Bohannan, P. (1959). The impact of money on an african subsistence economy. The Journal of Economic History, 19(4), 491-503.

Breton, S. (2002). Présentation: monnaie et économie des personnes. L’homme, Revue Française d'Anthropologie (162), 13-26.

Bryan, D., \& Rafferty, M. (2007). Financial derivatives and the theory of money. Economy and Society, 36(1), 134 - 158.

Cartelier, J. (2007). The hypostasis of money: an economic point of view. Cambridge Journal of Economics (37), 217-233.

Chopard, R. (1998). D'une analyse fonctionnelle de la monnaie à son approche « substantive ». In J.-M. Servet, J. Maucourant \& A. Tiran (Eds.), La modernité de Karl Polanyi (pp. 299-325). Paris: L'Harmattan.

Commons, J. R. (2005 [1934]). Institutional economics: Its place in political economy (2 vol.). New Brunwick (USA) and London: Transaction Publishers.

Courbis, B., Froment, E., \& Servet, J.-M. (1990). A propos du concept de monnaie. Cahiers d'Economie Politique, 18, 5-29.

Dalton, G. (1965). Primitive money. American Anthropologist, 67(1), 44-65.

Dodd, N. (2005). Reinventing monies in Europe. Economy and Society, 34(4), 558-583. 
Dutraive, V., \& Théret, B. (2011). Souveraineté et monnaie chez John Rogers Commons. Working Paper, seminar La souveraineté monétaire et la souveraineté politique en idées et en pratiques : identité, concurrence, corrélation? Paris: CERI.

Fantacci, L. (2005). Complementary currencies: a prospect on money from a retrospect on premodern practices. Financial History Review, 12(1), 43-61.

Graeber, D. (2009). Debt, violence and impersonal markets: Polanyian mediations. In C. Hann \& K. Hart (Eds.), Market and society: the great transformation today (pp. 106-132). Cambridge: Cambridge University Press.

Gregory, C. (2009). Whatever happened to householding? In C. Hann \& K. Hart (Eds.), Market and Society: The Great Transformation today (pp. 175-208). Cambridge: Cambridge University Press.

Grierson, P. (1978). The origins of money. Research in Economic Anthropology, 1, 1-35.

Guyer, J. (2004). Marginal gains: Monetary transactions in atlantic africa. London: The University of Chicago Press.

Hart, K. (1986). Heads or tails? Two sides of the coin. Man, 21(4), 637-656.

Hart, K. (2007). Money is always personal and impersonal. Anthropology Today, 23(5), 12-16.

Hart, K. (2009). Money in the making of world society. In C. Hann \& K. Hart (Eds.), Market and society: the Great Transformation today (pp. 91-105). Cambridge: Cambridge University Press.

Hart, K. (2011). The financial crisis and the end of All-Purpose money. Economic Sociology: the European Electronic Newsletter, 12(2), 4-10.

Helleiner, E. (2003). The making of national money : Territorial currencies in historical perspective. Ithaca: Cornell University Press.

Ingham, G. (2002). New monetary spaces? In OECD (Ed.), The future of money (pp. 123-145). Paris: OECD publication service.

Ingham, G. (2004). The nature of money. Cambridge: Polity.

Innes, A. (2004 [1913]). What is money? In R. Wray (Ed.), Credit and state theories of money: the contributions of A Mitchell Innes (pp. 14-49). Chettenham, Northampton: Edward Elgar.

Keynes, J. M. (1965 [1930]). A treatise on money (Vol. 2). London: Macmillan.

Knapp, G. F. (1973 [1905]). The state theory of money. London: MacMillan.

Kuroda, A. (2007). The Maria Theresa dollar in the early twentieth-century Red Sea region: a complementary interface between multiple markets. Financial History Review, 14(1), 89110. 
Kuroda, A. (2008). What is the complementarity among monies? An introductory note. Financial History Review, 15(01), 7-15.

Maucourant, J. (1994). La monnaie dans la pensée institutionnaliste (Veblen, Mitchell, Commons et Polanyi). PhD in Economics, University Lyon 2, France.

Maucourant, J. (2002). Polanyi on institutions and money: an interpretation suggested by a reading of Commons, Mitchell and Veblen. In F. Adaman \& P. Devine (Eds.), Economy and society: money, capitalism and transition (pp. 150-171). Montréal and London: Black Rose Books.

Maucourant, J. (2005). Le troc et la monnaie dans la pensée de Polanyi. In P. Clancier, F. Joannès \& P. Rouillard (Eds.), Autour de Polanyi : vocabulaires, théorie et modalités des échange (pp. 33-43). Paris: Editions De Brocard.

Meltiz, J. (1970). The Polanyi school of anthropology on money: an economist's view. American Anthropologist, 72(5), 1020-1040.

Menger, K. (1892). On the origin of money. The Economic Journal, 2(6), 239-255.

Moisseron, J.-Y. (2002). Money without exchange: theoretical reconsiderations. In F. Adaman \& P. Devine (Eds.), Economy and society: money, capitalism, and transition (pp. 134-149). Montréal and London: Black Rose Books.

Orléan, A. (2011). L'empire de la valeur. Paris: Seuil.

Ould-Ahmed, P. (2008). Le troc : une forme monétaire alternative. Décompositions monétaires en Russie, 1990-2001. In F. Lordon (Ed.), Conflits et pouvoirs dans les institutions du capitalisme. Paris: Presses de Science-Po.

Parry, J., \& Bloch, M. (Eds.). (1989). Money and the morality of exchange. Cambridge: Cambridge University Press.

Polanyi, K. (1948). Marxist Economic Thought [book review]. The Journal of Economic History, $8(2), 206-207$.

Polanyi, K. (1957). The economy as institued process. In K. Polanyi, C. M. Arensberg \& H. W. Pearson (Eds.), Trade and market in the early empires (pp. 243-270). New York: Trade Free Press.

Polanyi, K. (1966). Dahomey and the slave trade: An analysis of an archaic economy. Seattle: University of Washington Press.

Polanyi, K. (1968). The semantics of money uses. In G. Dalton (Ed.), Primitive, archaic and modern economies. Essays of Karl Polanyi (pp. 175-203). New York: Anchor Books.

Polanyi, K. (1977). The livelihood of man. New York: Academic Press.

Polanyi, K. (2001 [1944]). The great transformation. Boston: Beacon Press. 
Polanyi, K., Arensberg, C. M., \& Pearson, H. W. (Eds.). (1957). Trade and market in the early empires : Economies in history and theory. Glencoe, Ill: The Free Press.

Poulain, E. (1998). Les usages de la monnaie: donner, contribuer, échanger. In J.-M. Servet, J. Maucourant \& A. Tiran (Eds.), La modernité de Karl Polanyi (pp. 273-297). Paris: L'Harmattan.

Romano, R. (1998). Moneda, seudomonedas y circulacion monetaria en las economias de México. México: Fondo de Cultura Economica.

Rospabé, P. (1995). La dette de vie : aux origines de la monnaie sauvage. Paris: La Découverte.

Saiag, H. (2011). Le trueque argentin au prisme de la dette: Une socioéconomie des pratiques monétaires et financières. $\mathrm{PhD}$ in Economics, Université Paris-Dauphine, France.

Servet, J.-M. (1993). L’institution monétaire de la société selon Karl Polanyi. Revue Economique, 44(6), 1127-1150.

Servet, J.-M. (2001). Le troc primitif, un mythe fondateur d'une approche économiste de la monnaie. Revue Numismatique, 157(6), 15-32.

Servet, J.-M., Théret, B., \& Yildirim, Z. (2008). Universalité du fait monétaire et pluralité des monnaies : de la confrontation coloniale à la rencontre des sciences sociales. In E. Baumann, L. Bazin, P. Ould-Ahmed, P. Phélinas, M. Selim \& R. Sobel (Eds.), Argent des anthropologues, monnaie des économistes (pp. 167-207). Paris: L'Harmattan.

Smith, T. (1983). Wampum as primitive valuables. Research in Economic Anthropology, 5, 225245.

Théret, B. (2008). Les trois états de la monnaie. Approche interdisciplinaire du fait monétaire. Revue Economique, 59(4), 813-841.

Théret, B. (2009). Monnaie et dettes de vie. A propos de quelques critiques adressées à La monnaie souveraine. L'Homme, Revue française d'anthropologie (190), 153-180.

Théret, B. (Ed.). (2007). La monnaie dévoilée par ses crises. Paris: Éditions de l'EHESS.

Théret, B., \& Zanabria, M. (2009). Sur la pluralité des monnaies publiques dans les fédérations. Une approche de ses conditions de viabilité à partir de l'expérience argentine récente. Economie et Institutions, 40.

Wray, R. (Ed.). (2004). Credit and State theories of money: The contributions of A. Mitchell Innes. Cheltenham: Edward Elgar.

Zelizer, V. (1994). The social meaning of money. New York: Basic Books. 